\title{
Authentic Leadership and Work Engagement: The Mediatory Role of Employees' Trust and Occupational Self-efficacy
}

\author{
Syeda Amna Khali1 ${ }^{*}$, Danish Ahmed Siddiqui ${ }^{2}$ \\ ${ }^{1 *}$ University of Karachi, Karachi University Business School, Pakistan \\ ${ }^{2}$ University of Karachi, Karachi University Business School, Pakistan
}

Keywords:

Occupational Self-Efficacy, Work Engagement, Employee Trust, Authentic Leadership

\section{Received}

08 September 2019

Received in revised form

10 October 2019

Accepted

22 October 2019

Correspondence:

amnakhalil54@gmail.com

\begin{abstract}
This study examines the effect of authentic leadership on employee trust, occupational selfefficacy and work engagement. it also explores the mediating role of employees' trust and occupational self-efficacy on the relationship between authentic leadership and work engagement. The sample size of this study was 200 employees from different organizations of Pakistan and the quantitative method was used which includes questionnaires with close ended questions. Smart PLS software was used to measure the relationship among variables and different techniques for the analysis were adopted such as SEM Path Analysis and Confirmatory factor analysis. The results indicated a strong relationship among variables and supported that there is a direct and positive relationship between authentic leadership and work engagement and employee trust and occupational self-efficacy act as mediating tool to mediate and strengthen the relationship between authentic leadership and work engagement. This research found a strong and positive relationship among the variables and highlights the vital role that authentic leaders play in motivating employees to bring positive change in employee's attitude and behavior. The conclusions drawn will help to develop strategies so that the leaders may develop positive traits and workers may perform effectively and efficiently to enhance the productivity of an organization.
\end{abstract}

CCIKD Publishing

Leadership is an ability and eagerness to inspire and lead people in an organization to attain the objectives. It is a significant element to guarantee organizational sustainability not only due to dynamic environment but because of different challenges and difficulties that an organization faces on a daily basis. To endure in the competitive and intense conditions to cope with the change and to gain an edge an "organization needs a new generation of leaders-leaders not managers" (Bennis, 1989). Leaders have convincing idea of where things are going and create a captivating vision for the organizations and followers, provide them guidance, 
motivate them to meet the goals and encourage them with self-confidence and trust through coordination and communication (Bohn \& Grafton, 2002). Over the years, numerous studies have been conducted on various types of leadership and researchers in this field have added a lot of significant knowledge on leadership styles, qualities, behaviors, leader-follower relationship and other related areas. In recent years, interest in the field of authentic leadership has been developed among researchers (Darvish \& Rezaei, 2011) and emerged as a field that correlates work on ethical and transformational leadership in both practice, and academic literature (Avolio, Gardner, Walumbwa, Luthans, \& May, 2004; Harter, 2002; Ilies, Morgeson, \& Nahrgang, 2005). Authentic leadership means that leaders acts authentically required to stimulate workers' self-confidence, to strengthen their trust in management and coworkers (Avolio et al., 2004). Authentic leadership is considered a main component to positively impact employees' attitude and behavior including work engagement (Walumbwa, Wang, Wang, Schaubroeck, \& Avolio, 2010). Authentic leaders act genuinely and honestly which reflects who they are as an individual (Rouse, 2018) and they are self-aware of their strong and weak points, prioritize targets and mission of the organization (Kruse, 2013) and perform in a manner consistent to their values and beliefs (Avolio et al., 2004).

Organizations have realized to survive in a dynamic environment, to maintain organizational productivity and to gain an edge they must attract, engage and retain the most talented employees. The main concern for firms is to retain their enthusiastic and passionate employees and foster their commitment to organizational values (Babcock-Roberson \& Strickland , 2010). Work engagement has received significant consideration (Giallonardo, Wong, \& Iwasiw, 2010) frequently studied by organizational researchers and regarded as a possible key to address these issues (Oh, Cho, \& Lim, 2018). Work engagement is defined as 'a positive, fulfilling, work-related state of mind' (Schaufeli \& Bakker , 2003). Engaged workers are always eager to learn new information, they are more creative and are willing to make extra efforts to stay ahead at work. To remain engaged, they adopt a proactive approach to adapt to changes at the work environment (Bakker, 2011).

Trust is an essential element of the relationship between employees and organizations, and to become an effective leader, it is imperative to gain employees' trust (Wang \& Hsieh, 2013). Authentic leaders build and promote meaningful and trusting relationship with the employees that lead to favorable results (Hassan \& Ahmed , 2011). Work engagement of employees is also affected by the level of self-efficacy. Self-efficacy is defined as an individual's belief and confidence in their ability to accomplish a task or achieve an objective (Hopper, 2019). It is the core belief of an individual that acta as a motivator to face difficult situations, finding the solutions and complete a task to achieve favorable outcomes (Bandura, 1999).

Organization needs a positive and supportive environment to facilitate work engagement. Leadership plays an essential role and becomes a main driving force to foster such an environment. Effective leaders are capable to influence, and change employees' work attitudes and behaviors. (Tims, Bakker, \& Xanthopoulou, 2011). It has been proposed by recent findings that authentic leadership may have a positive impact on employees 'attitudes and behavior along with work results such as job satisfaction, commitment, originality and work engagement ( Rego , Sousa, Marques, \& Cunha, 2012; Walumbwa, Avolio, Gardner, Wernsing, \& Peterson, 2008; Walumbwa, Wang, Wang, Schaubroeck, \& Avolio, 2010). 


\section{Problem Statement}

In today's era of change, organizations have realized the importance of the role that employees play when they perform their duties, take part at work activities and contribute towards organizational growth and success through their knowledge, skills, and abilities. Without their support the organization cannot perform its basic functions well.

The capability, survivability and vivacity of the organization is affected by the work engagement of employees (Breevaart et al., 2013) and it is a challenge for the organizations to survive where everything is changing due to the technological advancement, innovation, changes in the government policies, and growing competition (Sweetman \& Luthans, 2010). Employees are required to adapt to these changes where they are expected to perform more complex tasks with less resources. Due to the increase in job demands, and the complexity of the tasks, employees' work engagement is affected. The job stress, workload, deadlines, requirement of high skills are some factors that reduce work engagement of employees and result in disengagement which has a negative effect on work performance.

Organizational performance is affected by the disengaged employee through high turnover rate (Wee, 2013) and in this turbulent environment where every organization is in need of talented workforce, it is the main concern for firms to retain their enthusiastic and passionate employees and foster their commitment to organizational values (Babcock-Roberson \& Strickland , 2010) so that they can contribute the most towards organizational success and help to gain a competitive edge over others.

The focus of the organization is to increase the engagement of the employees. Engaged employees are energetic, more dedicated towards their work, perform their duties enthusiastically and are more competitive to attain the goals. By promoting the employee's work engagement, it helps to overcome the issue of the turnover (Glen, 2006) that results in an increased loyalty towards organization and can enhance low productivity level (Brad \& Karen, 2010)

Employee work engagement is related with the positive and favorable outcomes, and therefore it is important to find the key element or the factor that fosters the work engagement in the most influential manner (Abidin \& Noraida, 2017). Leadership is the main factor that plays an essential role in providing a vision, and guidance to develop employees and creates an environment where the engagement of the employees is promoted. Leaders have a great influence on employees when they perceive their leader's behavior as authentic (Avolio, Gardner, Walumbwa, Luthans, \& May, 2004). Authentic leaders motivate employees, boost their confidence, give them the freedom to make the decisions and support them. Authentic leaders are genuine, and honest towards their employees and maintain transparency in an organization that helps to develop trusting relationships with them. This trusting relationship and an increased self-confidence results in an increased work engagement.

This study focuses on employees' perception of the leader's authentic behavior, and the role that authentic leaders play in fostering employee work engagement. It examines the relationship between authentic leadership and employee's attitude (Employee Trust and Occupational Self-efficacy) which plays a mediating role between authentic leadership and employee work engagement. 


\section{Gap Analysis}

In recent years, the concept of leadership has emerged as a field of interest among researchers (Avolio et al., 2004; George, 2003; Harter, 2002) but there are limited studies that have been conducted to examine the impact of authentic leadership on employee attitude and behavior including work engagement.

Leaders and employees depend on each other to attain personal and organizational goals, and the trust between them is an essential element that promotes a healthy work environment (Wong \& Cumming, 2009). A study conducted by Hassan and Ahmed (2011) found a significant relationship between authentic leadership, trust and employee work engagement and states that a leaders' honest and genuine behavior, feeling of responsibility, dedication and commitment level towards the organization builds a trusting relationship, and this trust fosters employee work engagement but this research is limited to banking sector of Malaysia and does not cover other sectors that have different surroundings and working environment. Another study conducted by Hsieh and Wang (2015) found a positive relationship between authentic leadership and employee work engagement and a mediating role of employee trust between these variables. The limitation of this study is that relationship was examined based on one variable, i.e., employee trust level, but there are other factors that affect employee's attitude, behavior and performance like psychological capital of employees (Avey, Reichard, Luthans, \& Mhatre, 2011).

Luthans, Avey, and Patera (2008) founds that high level of psychological capital results in a positive behavior and promotes the development of organization (Ilies, Morgeson, \& Nahrgang, 2005). They observed that authentic leaders play a vital role in promoting the psychological capital and (Gardner, Avolio, Luthans, May, \& Walumbwa, 2005) explained that when a leader exhibits a behavior of self-awareness, it has a positive impact on employees. A leader's engagement in making decisions that are based on key values reflects transparency in an organization which fosters trust level of employees and boosts their self-esteem and confidence and as a result increase the self-efficacy level.

Occupational self-efficacy is a construct of self-efficacy (one of the components of psychological capital) and (Guarnaccia, Scrima, Civiller, \& Salerno, 2016) there is a positive association between occupational self-efficacy and work engagement. A study conducted by Fallatah and Laschinger (2017) found that authentic leaders positively influence self-efficacy of employees by providing them new opportunities where different tasks are assigned to them that boost their self-confidence. This self-confidence leads to increase level of self-efficacy. This research is limited to service sector, i.e., healthcare industry and is not extended to other sectors of the economy.

Walumbwa et al. (2008) found a positive effect of authentic leadership and employee work engagement and (Abidin \& Noraida, 2017) concluded the positive impact of authentic leadership, it is important that employees perceive supervisor's behavior as authentic and genuine. When employees perceive the behavior as authentic and fair, they will tend to feel responsible to repay their leaders or organization for the benefits they receive and in return will be more engaged in their work. This research is limited to one sector only.

In Pakistan there are few and limited research on topic of authentic leadership and its impact on employee's attitude and behavior. Dar, Bukhari, and Hamid (2016) found a significant relationship between authentic leadership and employee work engagement but this research 
only covers the telecommunication sector of Pakistan. Another research done by Khan, Muhammad, Afridi, and Sarwar (2017) found the same positive effect of authentic leadership but again it was limited to public sector universities of Peshawar.

As the concept of authentic leadership is relatively new as compared to other styles of leadership, its impact is yet to be explored in detail, especially in the Pakistani context. To the best of our knowledge, no research has been done in Pakistan that examines the effect of authentic leadership on employees' attitude, i.e., employee trust, and occupational self-efficacy and employee work engagement.

The study aims to address gaps in literature and is conducted to examine the impact of authentic leadership and to find out what are the characteristics that leaders should develop to foster trust level of employees and to increase occupational self-efficacy. Previous researchers have kept their study limited to psychological capital, and have not studied the effects of occupational self-efficacy in detail. This study will help to understand its impact on employee's behavior. It also analyzes the vital role that authentic leaders play in influencing employee work engagement. Moreover, it explores the mediating role of trust and occupational selfefficacy between authentic leadership and employee work engagement. Most of the studies on the topic of authentic leadership have been conducted in developed countries and this research will help to contribute in the literature and will fill this gap by concentrating on developing country of Pakistan.

\section{Research Objectives}

The purpose of this research is to study the impact of authentic leadership on employee trust, occupational self-efficacy and work engagement level. There are few studies and limited evidence on the positive impact of authentic leadership in influencing trust level of employees, and an impact of increased trust level on work engagement. The study will help to expand the literature and investigate the said relationship. It also aims to explore the positive effect of high self-efficacy level. The previous researchers have focused on the impact of psychological capital, while the role of occupational self-efficacy (one of the components of psychological capital) in increasing employee's work engagement has not been studied in detail. Another purpose is to explore the mediating effect of trust and self-efficacy level between authentic leadership and employee work engagement.

The main objective of this study is to test the model using statistical tools to inspect and highlight the vital role that authentic leaders play in increasing the work engagement by promoting employee trust level and influencing occupational self-efficacy of employees and explores the mediating role of employees' attitude (employee trust and self-efficacy) on the relationship between authentic leadership and employee work engagement.

\section{Research Questions}

The research questions of the study are as follows:

What is the relationship between authentic leadership and employee work engagement?

Does authentic leadership affect employees' attitude (employee's trust and self-efficacy) in an organization?

Does the employee attitude mediate the relationship between authentic leadership and employees work engagement? 


\section{Significance of the Study}

The study will help the business sectors to gain insight about the importance of authentic leadership and help to better understand the value of developing authentic leaders by highlighting the vital role they play in motivating employees to bring positive change in their attitudes and its effect on work engagement. This study will suggest about characteristics that a leader should possess, and the behavior they should exhibit to bring favorable evolution in an organization. The suggestions presented in this study will help the organizations to introduce different leadership programs that should be provided to develop leaders.

This study will also highlight the importance of gaining employee trust and the positive effects of occupational self-efficacy that leads to the favorable outcomes and will help the leaders to find ways to promote trust level and boost self-efficacy of employees. It also emphasizes the importance of engaged workforce and the conclusions drawn will help the organization to develop strategies to increase work engagement of employees so that workers can perform effectively and efficiently and enhance the productivity of an organization.

\section{Theoretical Framework}

\section{Authentic Leadership and its Components}

Authentic leaders maximize their strengths, identify and overcome their shortcomings and take full responsibility for the effect on others (Robinson \& O’Dea, 2014). They are self-aware, passionate for the purpose, consistent to their values, and beliefs and listens to their heart and mind when leading people to build significant relationships with them (George, Sims, McLean, \& Mayer, 2007).

Due to the dynamic and competitive environment, it is important for a leader to remain positive, self-aware and confident. The positive attitude and behavior of a leader is the key driving force that motivates, encourages and inspires the employees to accomplish their tasks effectively. Leaders have great influence on employees when they perceive their leader's behavior as authentic (Avolio, Gardner, Walumbwa, Luthans, \& May, 2004). The theory of authenticity has deep roots in ancient Greek philosophy and is defined as "owning one's personal experiences, be they thoughts, emotions, needs, wants, preferences, or beliefs, processes captured by the injunction to "know oneself." (Harter, 2002). The concept of authentic leadership emerged as a field of interest among researchers in the early 1980s (Oh, Cho, \& Lim, 2018) and has received much attention after Bill George's book 'Authentic Leadership' in 2003 (Robinson \& O’Dea, 2014).

Authentic leadership was initially defined by Luthans and Avolio "as a process that draws from both positive psychological capacities and a highly developed organizational context which results in both greater self-awareness and self-regulated positive behaviors on the part of leaders and associates, fostering positive self-development" (Luthans \& Avolio, Authentic Leadership Development, 2003). Authentic leadership was further defined by (Walumbwa, Avolio, Gardner, Wernsing, \& Peterson, 2008) as " a pattern of leader behavior that draws upon and promotes both positive psychological capacities, and a positive ethical climate, to foster greater self-awareness, an internalized moral perspective, balanced processing of information, and relational transparency on the part of leaders working with followers, fostering positive self-development." This definition is a modified form of initial definition by (Luthans \& 
Avolio, Authentic Leadership Development, 2003). It reflects the four components of authentic leadership:

1) Self-Awareness refers to behavior of the leader which reflects the understanding of Strengths and weaknesses, specific needs, wants, motives and purposes. It is a process that helps a leader to discover about him-herself, to develop self-esteem and to learn how their experiences affect their vision and behavior (Kernis, 2003). 2) Relational Transparency refers to a display of behavior which exhibits the genuine and true self to the employees as compared to a false or distorted self (Walumbwa, Avolio, Gardner, Wernsing, \& Peterson, 2008). Such behavior builds and promotes trust through open communication of ideas, views, opinions and sharing of information in a good manner (Kernis, 2003). 3) Balanced processing refers to behavior of the leader who analyzes all the related information and data objectively prior to any decision. Such leaders are not afraid to solicit challenging and different views from employee (Gardner, Avolio, Luthans, May, \& Walumbwa, 2005). 4) Internalized moral perspective refers to self-regulation which is directed by internal moral ethics and values. It leads to performances and decisions that are consistent to their values and beliefs, and it is not influenced by groups or any social pressures (Avolio \& Gardner, 2005; Gardner, Avolio, Luthans, May, \& Walumbwa, 2005).

It is important that employees perceive supervisor's behavior as authentic and genuine because a trusting relationship between supervisor and employee is dependent on employees' perception (Hsieh \& Wang, 2015). The perception of employee is developed through social exchanges which means when a leader is honest and genuine towards their employees, openly communicates to them, maintains transparency in an organization, acts in accordance with the values and beliefs, and the employees perceive these exchanges as authentic and fair, they will tend to feel responsible to repay their leaders or organization for the benefits they receive and in return will be more engaged in their work (Blau, 1964). A win win situation is created for both supervisor and employees when the leaders exhibit their authentic behavior, are concerned about the problems of their employees, guide them, provide solutions to the complex problems, and support them by encouraging them and the employees perceive that the supervisor values their feelings, it results in an increased work engagement (Hsieh \& Wang, 2015).

\section{Employee Trust and its Components}

Employee trust is defined as "the emotional glue that binds followers and leaders together ... It cannot be mandated or purchased; it must be earned. Trust is the basic ingredient of all organizations" (Bennis \& Nanus, 1985). Trust is an essential element to working relationships (Blau, 1964) and a key component of organizational success (Block, 1993). It is imperative to gain, and win employees' trust (Wang \& Hsieh, 2013) as it is the direct and influential way for a leader to boost organizational outcomes (Shaw, 1997). The ability to create a vision and trust are the two main factors of effective leadership (Korthuis-Smith, 2000) as the trusting relationship with employees helps them to feel secure where they are free to share their ideas, opinions, thoughts and can work together on different tasks and projects.

Trust is an essential construct and building block of social exchange theory. The theory states that when a leader and supervisor interacts in high-quality relationship it evolves in an increased trust and commitment level where leaders are obliged to display behavior which 
exhibits the genuine and true self to the employees, and in return employees will tend to feel responsible to repay them by engaging in their work activities to achieve goals in an effective manner (Blau, 1964). Supervisor's authentic leadership is consistent with the perception of employee. This consistency of supervisor's action / employee perception, and trust results in the cooperation between them and improves employees' work engagement (Hsieh \& Wang, 2015)

Authentic leadership is more influential in developing and promoting trust relationship as compared to other styles of leadership (Avolio, Gardner, Walumbwa, Luthans, \& May, 2004). Previous studies have found a positive relationship between authentic leadership and employee trust level. Leaders have a major impact on employees' commitment and participation level towards an organization, and it is the leader's authentic behavior that helps to develop a positive attitude of employees. The four constructs of authentic leadership are said to be predictors of trust in an organization (Hassan \& Ahmed , 2011). The authentic, fair and honest behavior towards their employees maintain the transparency in an organization, increase employee trust level (Norman, 2006) and the belief in the leader's capability, honesty, and integrity influences employees to participate in the risk taking behavior ( Mayer, Davis, \& Schoorman, 1995) that results in organizational commitment and directly leads to increase work engagement (Dirks $\&$ Ferrin, 2002). An effective communication is a key to building trust. When a leader openly shares ideas, opinions and clearly states what is expected from them, employees will trust their leader more and will be more willing to get themselves engaged (Hsieh \& Wang, 2015). It has been found that employee's trust is promoted by authentic leadership and trust level act as a mediator between employee-perceived authentic leadership and work engagement (Hassan \& Ahmed , 2011; Hsieh \& Wang, 2015).

There are two constructs of Trust, i.e., affect based trust and cognition-based trust; to build a relationship with the employees both the constructs must be developed. Cognition-Based Trust also referred to trust "from the head" is the judgment based on knowledge of another's ability and trustworthiness. It is developed on rational analysis of leader's competencies and performances (Chhetri, 2014). In the cognition-based trust "we choose whom we will trust in which respects and under what circumstances, and we base the choice on what we take to be 'good reasons, constituting evidence of trust worthiness." The foundation of cognition-based trust is based on the available knowledge and Good reasons (Lewis \& Weigert, 1985). AffectBased Trust also referred to trust "from the heart" is based on the emotional attachments that link the individuals (Chhetri, 2014). The foundation of affect-based trust is the emotional investment that an individual makes in trust relationships and it is built on belief of genuine care and concern (McAllister, 1995).

\section{Employee Self-efficacy and its Sources}

Self-efficacy is defined as "beliefs in one's capabilities to organize and execute the courses of action required to produce given attainments" ( Bandura, 1997). It is an encouraging factor that has deep roots in core belief that one has the power to bring change through his/her actions. It is the way the people think, act and encourage themselves. It acts as a motivator to face difficult situations, finding the solutions and complete a task to achieve favorable results and stimulates the individual to make decisions and act in given situation (Bandura, Social Cognitive Theory: An agentic perspective, 1999). There are three different ways to understand self-efficacy, i.e., 
general self-efficacy, task-specific self-efficacy, and domain-specific self-efficacy. Occupational self- efficacy is classified into domain self-efficacy which means it is concerned to the workplace domain (Kim, 2014) and can be defined as the employee's belief in his/her capability to successfully implement educational requirements and perform his/her job ( Schyns \& Collani, 2002). Self-efficacious individuals believe that they can perform certain task, do not hesitate to face difficult situations, set goals, take risks and exert necessary efforts to achieve the goals (Roux, 2010). Self-efficacy has an impact on behavior of individual and the efforts made by them depend on the level of self-efficacy.

Self-efficacy has an impact on individual's behavior, and the concept is based on individual's perception of specific behavior and is said to be situation specific (Kurbanoglu, Akkoyunlu, \& Umay, 2006) which means that an individual may exhibit a high level of selfefficacy in one situation while low level of self-efficacy in another (Cassidy \& Eachus, 2002). It determines the efforts exerted by an individual to perform certain activity as well as their persistence and resistance level while facing difficult situations. Individuals with positive selfefficacy tends to be successful as they are persistent in performing their tasks effectively; however, individuals with low level of self-efficacy predict failure, are reluctant to take risks or challenging roles and are less likely to survive difficult situations (Kurbanoglu, Akkoyunlu, $\&$ Umay, 2006). The direct/indirect experience with the success/failure affects the self-efficacy of an individual and can be promoted by the efforts of others like the leader's confidence in their employees that help them to achieve a high level of self-efficacy in the workplace (Eden, 2003).

Self-efficacy is one of the components of psychological capital, and it is claimed by ( Avolio \& Luthans, 2006) that authentic leadership plays an important role in developing and promoting it by exhibiting confidence in employees which in turns increases hope and selfefficacy and results in an increased expectations and achievement of success. The confidence of authentic leaders in their employees motivates them to accept challenging roles to accomplish goals to become more resistant to stress and carry out difficult task with positive thoughts (Gardner \& Schermerhorn, 2004). A study conducted by Kim (2014) found a significant and positive relationship between authentic leadership and occupational selfefficacy and emphasized that a leader's authentic behavior, his/her honesty towards employees, self-awareness, rational decision-making and transparency in an organization influences the attitude of employees and increases occupational self-efficacy which results in positive outcomes, i.e., increased work engagement and a high job performance. Thus, to maximize the level of self-efficacy, a leader should remain genuine and honest to their employees and have a close relationship with them to inspire them and to boost their self-efficacy. (Bandura, 1982) defined four sources that influence the level of self-efficacy.

Mastery Experiences: An individual experience of success helps to create and strengthen a strong sense of efficacy, but experience of failure weakens it especially if an individual faces failure before self-efficacy is established. The difficulties and obstacles help an individual to learn that success is not always easy, and it requires effort to achieve desired results. Once an individual learns this lesson, he/she won't hesitate to take risks and will be stronger to face difficult situations. The experience of success helps to build the confidence and diminish the negative effect of failures. 
Vicarious experiences: When an individual see that other people are successful through their continuous efforts, it stimulates and boosts their confidence that they are also capable to perform the activities and tasks that are needed to be successful. Vicarious experience is more effective when individual considers him/herself like another person.

Social Persuasion: Self-efficacy is also affected when an individual is encouraged and motivated to perform better. This appraisal from a leader, supervisor or a colleague helps $\mathrm{him} / \mathrm{her}$ to invest more time and exert necessary efforts to accomplish goals

Physiological state: an individual physiological state may have an impact on self-efficacy. When he/she is stressed, in pain or not feeling better, it will impact their self-efficacy and result in poor performance. Positive mood enhances the productivity level, negative mood decreases it.

\section{Work Engagement and its Constructs}

Work engagement is defined as 'the harnessing of organization members' selves to their work roles; in engagement, people employ and express themselves physically, cognitively, and emotionally during role performances" (Kahn, 1990). Engaged employees are energetic, and they are willing to go the extra mile to get the work done. Employees who invest their time and make additional efforts to work effectively for the organization improve their performance. (Schaufeli, Salanova, González-romá, \& Bakker, 2002) defined work engagement as “a positive, fulfilling, work-related state of mind that is characterized by vigor, dedication, and absorption."

The concept of work engagement can be explained by social exchange theory. Many researchers have analyzed manager- employee relationship based on this theory which is founded on the principle of reciprocity. It is found by Gerstner and Day (1997) that the highquality relationship of employees with their supervisor influences their motivation levels and leads to a positive attitude and behavior Saks (2006) found a positive relationship between work engagement and organizational citizenship behavior and highlighted the fact that employees will be more engaged in their work and will contribute cognitive emotional and material resources as they feel responsible to repay in exchange for the benefits they receive from the organization. Work engagement of employees is predicted by the level of trust in the leadership, and the degree of integrity exhibited by authentic leaders, their commitment towards essential values, and a deep sense of responsibility to build and promote meaningful and trusting relationship with them that lead to favorable results (Hassan \& Ahmed , 2011).

Mills, Fleck, and Kozikowski (2013) emphasize that authentic leadership is the best style in positive leadership theories that stimulates employees as their behavior is driven by selfawareness and ethical values which fosters positive development of employees. Dar, Bukhari, and Hamid (2016) found a positive relationship between authentic leadership and employee work engagement and highlighted that the authenticity displayed by the leaders will result in an increased work engagement as employees get the guidance and advice of their leaders and as a result will be more involved in their work. Hsieh and Wang (2015) stated that when a leader openly shares ideas, opinions and clearly states what is expected from the employees, they will trust their leader more and will be more willing to get themselves engaged in their work. Employees always trust their leaders when they are consistent between their words and actions, and this consistent behavior fosters employees' work engagement. Abidin and Noraida (2017) 
found a significant relationship and indicated that balanced processing behavior of authentic leader positively impacts work engagement of employees and when employees perceive the behavior as authentic and fair, they will tend to feel responsible to repay their leaders or organization for the benefits they receive and in return will be more engaged in their work

Employee's work engagement is a strong predictor of job performance as engaged employees are energetic, creative and proactive in performing their tasks, take different initiatives, make necessary changes and are willing to go an extra mile to get the work done. They make additional efforts to improve their performance and work effectively for the organization (Bakker, 2011). Thus, it is concluded when a leader understands the emotions of employees and provides them an environment where they are encouraged, supported and developed, and the employees perceive the behavior of their leader as authentic, it results in an increased work engagement. The three constructs of work engagement are: 1) Vigor refers to the exhibition of high level of energy, willingness to make additional efforts to remain calm and flexible during work and to remain consistent even in difficult situations, 2) Dedication is characterized by a sense of significance, enthusiasm, inspiration, pride, and challenge, and 3) Absorption is characterized by "being fully concentrated and deeply engrossed in one's work, whereby time passes quickly, and one has difficulties with detaching oneself from work.

\section{Relationship among variables and Hypothesis Development}

\section{Authentic Leadership, Employee Trust and Work Engagement}

Employee trust is the fundamental element that leads to organizational success and plays a vital role when it comes to the promotion of healthy work environment where the employees are energetic, motivated and more engaged towards their work. An important element of effective leadership is to gain and win employee trust and requires consistency between leader's beliefs and actions that will help to create a lasting relationship with the employees (Jiang \& Luo, 2018). Leaders play a key role and becomes a role model when it comes to win employee trust and the foundation of this relationship with employees should be built on authenticity which means that leader should be genuine and honest. Transparency is the main component of authentic leadership and considered as a key element to build trust. Authentic leaders are selfaware of their strengths and weaknesses, perform in a manner that is consistent to their values and beliefs, and are always genuine to their employees (Avolio, Gardner, Walumbwa, Luthans, \& May, 2004). Employees always trust leaders when they are consistent between their words and actions, and openly communicate opinions, ideas and information. Numerous studies have found a positive relationship between authentic leadership and employee trust (Hassan \& Ahmed , 2011; Wang \& Hsieh, 2013) but there is limited empirical research in Pakistan, therefore we propose the following hypothesis:

H1: Authentic Leadership will positively influence employee trust.

The relationship between employees' trust and work engagement is explained by social exchange theory (Blau, 1964) which is founded on the basis of reciprocity. When an employee feels there is transparency in an organization, and he/she is being treated fairly trust will be developed, and this trust will influence an employee to repay the organization by exhibiting 
positive behavior such as work engagement ( Ugwu, Onyishi, \& Rodri'guez-Sa'nchez, 2014). Trust in leader will motivate the employee to engage in their work and to get it done effectively. Thus, we propose the following hypothesis:

H2: Employee trust will positively influence work engagement.

\section{Authentic Leadership, Occupational Self-efficacy and Work Engagement}

There are four components of psychological capital, i.e., self-efficacy, hope, optimism, and resilience. Self-efficacy of an employee serves as a motivating tool that stimulates an employee to take risks in difficult situations, make decisions and participate in different work activities. The level of self-efficacy differs and is affected by the different sources. Authentic leaders are not only self-aware of their strengths, and weaknesses but also of their employees and it is their confidence that helps the employee to achieve a high level of self-efficacy by emphasizing on their strengths, and help them to overcome their weaknesses. Thus, to maximize the level of self-efficacy, a leader should remain genuine and honest to their employees and have a close relationship with them to inspire them and to boost their self-efficacy. Self-efficacy is one of the components of psychological capital, and it can be claimed that authentic leadership have an impact on self-efficacy ( Avolio \& Luthans, 2006), thus we hypothesize the following:

H3: Authentic leadership will positively influence employees' self-efficacy.

Authentic leaders promote a healthy work environment to encourage the concept of selfawareness and self-development. When an employee perceives the authentic behavior of the leader, it positively influences their attitudes and results in high self-confidence, trust and increased work engagement. We propose the following hypothesis:

H4: Employees' self-efficacy will positively influence work engagement.

\section{Authentic Leadership and Employee Work engagement}

When employees recognize their leader as authentic, genuine and honest, their commitment and loyalty towards organization will be increased. This commitment will lead to work engagement. Engaged employees are more energetic and enthusiastic to get the work done effectively, and they are motivated to learn and develop their skills and have low intention to leave the organization. The trust that is built through relational transparency and the efficacy that is boosted by the confidence and encouragement of authentic leader will result at work engagement. It is concluded that authentic leadership plays an important role to promote healthy work environment by exhibiting the positive behavior that results in an increased level of self-efficacy and the trusting relationship with the employees. we propose the following hypothesis:

H5: Authentic leadership will positively influence employee work engagement.

H6a: The relationship between authentic leadership and work engagement will be mediated by employees' trust. 
H6b: The relationship between authentic leadership and work engagement will be mediated by employees' occupational self-efficacy.

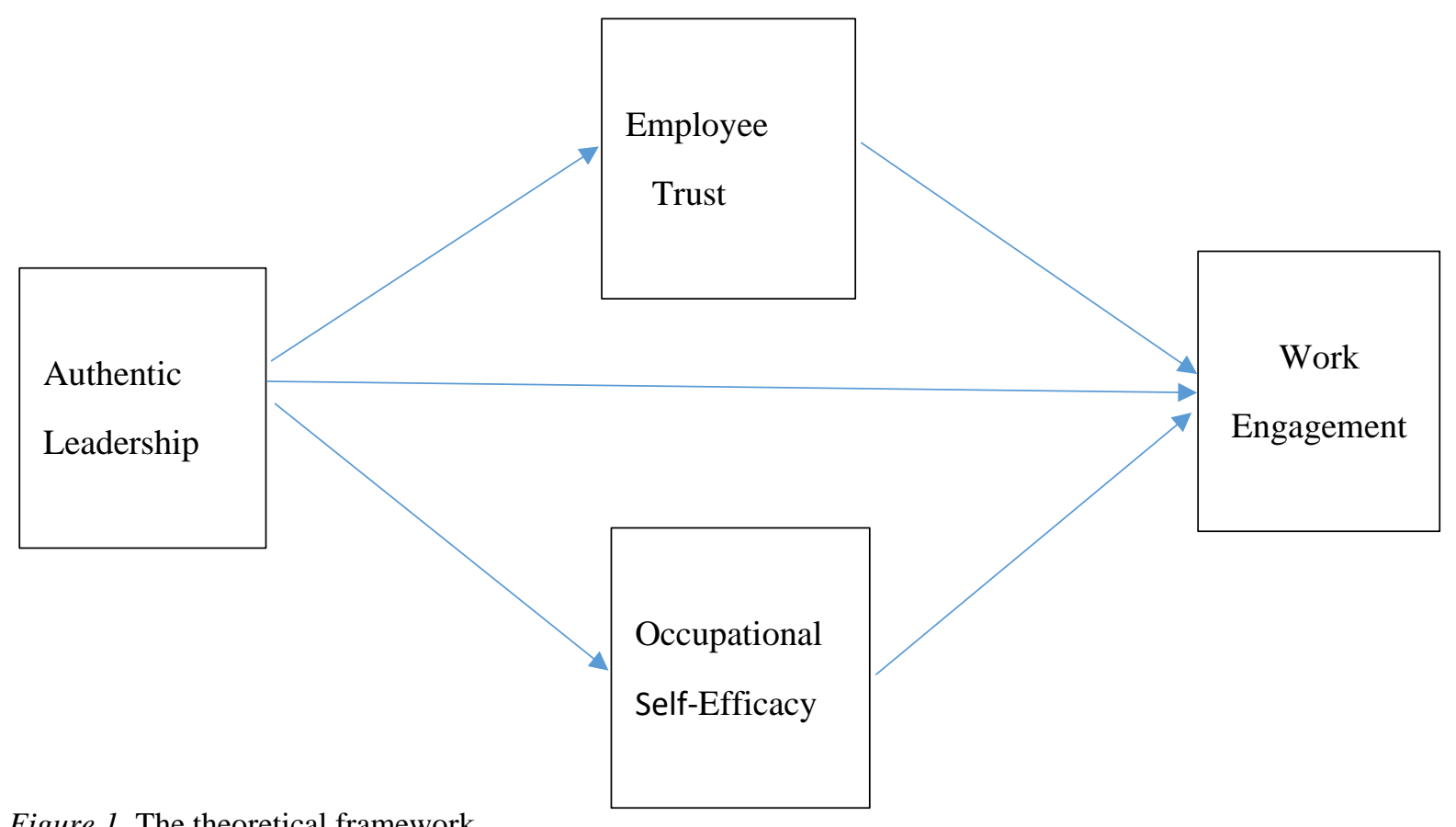

Figure 1. The theoretical framework

As shown in Figure 1, the theoretical framework shows the relationship between authentic leadership and employee work engagement with the mediating role of employee trust and employee self-efficacy. It exhibits the impact of authentic leadership on employee trust where authentic leadership is an independent variable and employee trust is the dependent variable, and then the relationship between employee trust and work engagement where trust is an independent variable and engagement is the dependent variable. It demonstrates the impact of authentic leadership on occupational self- efficacy and then impact of occupational selfefficacy on work engagement.

\section{Method}

This research is descriptive in nature, and quantitative research method is used to find the impact of authentic leadership on employee work engagement and the mediating role of employee trust and occupational self-efficacy. In this research, convenience sampling technique was used, a type of non-probability sampling method where the sample is taken from a group of people who are easily accessible. The sample chosen for this research comprised of 200 employees working in different organizations in Pakistan. Primary and secondary data collection method is being used in this research. The data is collected through primary source through questionnaires with close ended questions.

\section{Instruments}

In this study, we have used the instruments that were already developed and validated by researchers and supported by many studies mentioned in literature review. The questionnaires used in this research are as follows: 
Authentic Leadership Questionnaire. Authentic leadership inventory questionnaire developed by (Neider \& Schriesheim, 2011) was adapted to measure the four components of authentic leadership, i.e., self-awareness relational transparency, balanced processing and internalized moral perspective.

Employee Trust. Employee trust was measured using (McAllister, 1995) 11 item scale composed of a five-item affect-based trust sub scale and a six-item cognition-based trust subscale. We have selected four items ( 2 from each sub scale) to explore the mediating role of employee trust.

Occupational Self-efficacy Questionnaire. Employee occupational self-efficacy was measured using a short version of the occupational self-efficacy scale (Rigotti, Schyns, \& Mohr, 2008). In this research we have selected three items from this scale to explore the mediating role of occupational self-efficacy.

Work Engagement. Employee work engagement was assessed by using the Utrecht Work Engagement Scale developed by Schaufeli and Bakker (2006) composed of three sub scales, i.e., vigor, dedication and absorption. We have selected nine items (3 items from each sub scale) to measure employee work engagement.

\section{Data Analysis}

Gender, age and tenure are the control variables in this research and may have an impact on employee work engagement (Sonnentag, 2003; Walumbwa, Wang, Wang, Schaubroeck, \& Avolio, 2010). As presented in Table 1, 200 employees participated in this survey in which male employees were $129(64.5 \%)$ and female employees were 71 (35.5\%). Mostly the respondents belonged to the age group of 25-29 years (47\%). 30\% have 1-3 years of experience, $28.5 \%$ have 3-6 years of experience, $22 \%$ have less than a year experience, $10.5 \%$ have $6-9$ years and $9 \%$ have more than 10 years of experience.

Table 1

Descriptive Statistics of the Participants

\begin{tabular}{|c|c|c|c|}
\hline Variables & Groups & Frequency & Percentage \\
\hline \multirow[t]{2}{*}{ Gender } & Female & 71 & 35.5 \\
\hline & Male & 129 & 64.5 \\
\hline \multirow[t]{5}{*}{ Age } & $20-24$ & 61 & 30.5 \\
\hline & $25-29$ & 94 & 47 \\
\hline & $30-34$ & 33 & 16.5 \\
\hline & $35-39$ & 10 & 5 \\
\hline & Above 40 & 2 & 1 \\
\hline \multirow[t]{5}{*}{ Tenure } & Less than a year & 44 & 22 \\
\hline & $1-3$ years & 60 & 30 \\
\hline & 3-6 years & 57 & 28.5 \\
\hline & $6-9$ years & 21 & 10.5 \\
\hline & More than 10 years & 18 & 9 \\
\hline
\end{tabular}

As shown in Table 2, authentic leadership is an independent variable consists of 8 items and the mean value of the items lie within the range of 3.68-3.86. The overall mean value is above average, and it is more towards "Agree" at five-point Likert scale. The standard deviation ranges between .80 and .99 which indicates that the data is not dispersed and is close to the mean value of data. 
Table 2

\begin{tabular}{|c|c|c|c|}
\hline Questions & $M$ & $S E$ & $S D$ \\
\hline 1.My leader is clearly aware of the impact he/she has on others & 3.86 & .06 & .87 \\
\hline 2. My leader shows that he/she understands his/her strengths and weaknesses & 3.83 & .06 & .85 \\
\hline 3. My leader clearly states what he/she means & 3.68 & .07 & .99 \\
\hline $\begin{array}{l}\text { 4. My leader openly shares information and expresses his/her ideas and thoughts clearly to } \\
\text { others }\end{array}$ & 3.70 & .06 & .88 \\
\hline 5. My leader objectively analyzes relevant data before making a decision & 3.80 & .05 & .83 \\
\hline $\begin{array}{l}\text { 6. My leader carefully listens to alternative perspectives before } \\
\text { reaching a conclusion. }\end{array}$ & 3.75 & .05 & .82 \\
\hline 7. My leader uses his/her core beliefs to make decisions & 3.85 & .05 & .80 \\
\hline 8. My leader shows consistency between his/her beliefs and actions & 3.80 & .05 & .82 \\
\hline
\end{tabular}

Employee trust and self-efficacy are the mediating variables. As indicated in Table 3, there are 4 items of employee trust, and the mean value ranges between 3.75 and 3.83. Mean value of 2 nd and 4th item is 3.83 with the standard deviation of .79 and .77 . The overall mean value is above average, and it is more towards "Agree" at five-point Likert scale. The standard deviation of 4 items ranges between .77 and .83 which indicates that the data is not dispersed and is close to the mean value of data.

There are 3 items of occupational self-efficacy. 1st, 2nd and 3rd items have the mean value of $3.85,3.81$ and 3.83 which indicates that the mean value is above average. The standard deviation ranges between .84 and .93 . The mean values of both mediating variables are almost the same but the standard deviation of self-efficacy is slightly more than employee trust.

Table 3

Employee Trust and Occupational Self-Efficacy Questionnaire

\begin{tabular}{|c|c|c|c|}
\hline Questions & $M$ & $S E$ & $S D$ \\
\hline 1. I can talk freely about difficulties at work and know that (s) he will want to listen. & 3.86 & .05 & .83 \\
\hline 2. If I share my problems, I know (s) he would respond constructively and caringly & 3.83 & .05 & .79 \\
\hline 3.My leader approaches his/her job with professionalism and dedication. & 3.75 & .05 & .80 \\
\hline 4. I can rely on my leader not to make my job more difficult by careless work & 3.83 & .05 & .77 \\
\hline 5. I can remain calm when facing difficulties in my job because I can rely on my abilities & 3.85 & .06 & .84 \\
\hline 6. When I am confronted with a problem in my job, I can usually find several solutions & 3.81 & .06 & .87 \\
\hline 7. My past experiences in my job have prepared me well for my occupational future & 3.83 & .06 & .93 \\
\hline
\end{tabular}

Employee work engagement is an independent variable consists of 9 items. The mean value of items lies within the range of 3.67-3.98 which indicates that the mean values are above average and more towards "Agree" at five-point Likert scale, as shown in Table 4. The standard deviation ranges between .88 and.97 which indicates that the data is not dispersed and is close to the mean value of data.

Table 4

Employee Work Engagement Questionnaire

\begin{tabular}{|c|c|c|c|}
\hline Questions & Mean & $S E$ & $S D$ \\
\hline 1. At my work, I feel bursting with energy & 3.81 & .06 & .91 \\
\hline 2. At my job, I feel strong and vigorous & 3.71 & .06 & .88 \\
\hline 3. When I get up in the morning, I feel like going to work & 3.71 & .06 & .91 \\
\hline 4. I am enthusiastic about my job & 3.67 & .06 & .97 \\
\hline 5. My job inspires me & 3.75 & .06 & .97 \\
\hline 6. I am proud of the work that I do & 3.96 & .06 & .88 \\
\hline 7. I feel happy when I am working intensely & 3.92 & .06 & .91 \\
\hline 8. I am immersed in my work & 3.87 & .06 & .93 \\
\hline 9.I get carried away when I am working & 3.98 & .06 & .89 \\
\hline
\end{tabular}




\section{Structural Equation Modeling}

To test the study hypotheses, we have applied the structural equation model (SEM) using Smart PLS software. Moreover, the indirect and direct effects of all the constructs were evaluated. The use of SEM is a foremost procedure that has been used below with different regression models and methods (Baron \& Kenny, 1986). It was used to evaluate the structural relationship between exogenous and endogenous variables. It includes factor analysis, and multivariate analysis. Moreover, the equation of regression targets at explaining each construct to assess the cause and effect relationship while all the factors in the causal model could demonstrate their cause and effect at exact time. Likewise, the idea of using this model ensures to apply technique of bootstrapping which has been viewed as reasonable for both small and large sample size and does not require any kind of indirect effect (Hayes, 2013). In order to check all direct and indirect effects, a technique has been implemented which is known as bootstrapping (Shrout \& Bolger, 2002).

\section{Measurement of Outer Model}

The goal of measure of fit in the measurement model is to study the reliability and validity of the instrument which convergent validity and discriminant validity were performed to that end:

\section{Composite Reliability}

Reliability implies stability of questionnaire outcomes. For the similar target population, at whatever point the questioner reutilizes the questionnaire, it will give similar outcome. It demonstrates that inside consistency and repeatability of the survey is high. The primary measure for unwavering quality is to maintain a strategic distance from unfairness in research. In this manner, it tends to be improved by testing the pursuit procedure and investigation, as this is done by utilizing diverse research and examination techniques by different researchers. This also incorporates the dependability and legitimacy of the exploration.

Reliability of the measurement instruments was evaluated using composite reliability. All the values were above the normally used threshold value, i.e.,.70. This is the accepted reliability value range. Estimation of reliability can be done by degree of constancy that lies amongst various variables. Table 5 shows the results of composite reliability.

Table 5

The Results of Composite Reliability

\begin{tabular}{ll}
\hline Variables & Composite Reliability \\
\hline Authentic Leadership & .89 \\
Employee trust & .86 \\
Occupational Self-efficacy & .89 \\
Work engagement & .94 \\
\hline
\end{tabular}

\section{Convergent Validity}

Convergent validity is the level of agreement in at least two measures of a similar construct (Carmines \& Zeller, 1979). Convergent validity was assessed by inspection of variance mined for each factor (Fornell \& Larcker, 1981). According to Fornell and Larcker (1981), if the variance extracted value is greater than .5 , then convergent validity is established and the result is drawn that the loadings are good. The results of convergent validity are represented in Table 6 below. 


\section{Cronbach's Alpha}

To measure the reliability and consistency of the instrument, Cronbach's alpha was used in this study. The instrument is said to be reliable, valid and consistent if the value of Cronbach's alpha is greater than .7 and the ideal value of Cronbach's alpha lie within range of .7-1. As presented in Table 6 below, Authentic leadership is an independent variable consists of 8 items and the Cronbach's alpha value is .86 which indicates the reliability and internal consistency of items. The value of Cronbach's alpha for the employee trust with 4 items is .80 and for the occupational self-efficacy which consist of 3 items is .82. The Cronbach's alpha value for both the mediating variables is greater than .7 which reflects reliability and consistency. Employee work engagement is a dependent variable with 9 items has Cronbach's alpha value of .93 also reflects reliability. Hence, the independent, mediating and dependent variables show consistency, validity and reliability.

\section{Spearman Rank Correlation}

The association among variables and their strength is indicated by the Spearman rank correlation and the column next to Cronbach's alpha depicts it, shown in Table 6. The correlation value of authentic leadership (.87), employee trust (.84), occupational self-efficacy (.82) and employee work engagement (.93) shows that the association among the variables is strong.

\section{Average Variance Extracted (AVE)}

As demonstrated in Table 6, the average variance for variables are .50, .62, .74, .66 and as the value is greater than .5 , it indicates the loading under these variables are good enough to support convergent validity.

Table 6

The Results of Convergent Validity

\begin{tabular}{|c|c|c|c|c|c|}
\hline Variables & $\begin{array}{l}\text { No of } \\
\text { Items }\end{array}$ & $\begin{array}{c}\text { Cronbach's } \\
\text { Alpha }\end{array}$ & rho_A & Composite Reliability & $\begin{array}{l}\text { Average } \\
\text { Variance }\end{array}$ \\
\hline Authentic Leadership & 8 & .86 & .87 & .89 & .50 \\
\hline Employee trust & 4 & .80 & .84 & .86 & .62 \\
\hline Occupational Self-efficacy & 3 & .82 & .82 & .89 & .74 \\
\hline Work engagement & 9 & .93 & .93 & .94 & .66 \\
\hline
\end{tabular}

\section{Factor Loadings Significant}

Table 7 shows the confirmatory factor analysis (CFA) with the loadings. Constructs with the loading of .5 are considered strong loading variables whereas the constructs with the loading of below .5 are considered less, which should be removed from the table. The value of the loading above .5 is considered strong loading variable and below .5 is considered weak and it should be eliminated to ensure the consistency of path analysis model. The loading values of all the constructs related to authentic leadership, employee trust, occupational self-efficacy and employee work engagement are more than.7 except A1 that is .61 and A2 that is .60 which are also above .5 , thus it supports strong loading values. Moreover, the $t$ values of all the constructs are more than 1.96 and $p$ values are less than .05 (more than 99 percent confidence). 
Table 7

Confirmatory Factor Analysis (CFA) with the Loadings

\begin{tabular}{lllll}
\hline Variables & Constructs & Item loading & $t$ & $p$ \\
\hline Authentic Leadership & A1 & .61 & 11.26 & .000 \\
& A2 & .60 & 11.30 & .000 \\
& A3 & .74 & 16.50 & .000 \\
& A4 & .77 & 15.71 & .000 \\
& A5 & .71 & 12.18 & .000 \\
& A6 & .76 & 14.38 & .000 \\
& A7 & .75 & 21.94 & .000 \\
Employee Trust & A8 & .72 & 18.23 & .000 \\
& T1 & .78 & 38.31 & .000 \\
& T2 & .76 & 12.81 & .000 \\
Occupational Self-efficacy & T3 & .78 & 13.83 & .000 \\
& T4 & .82 & 19.60 & .000 \\
& E1 & .87 & 37.27 & .000 \\
Employee Work Engagement & E2 & .86 & 42.08 & .000 \\
& E3 & .85 & 36.97 & .000 \\
& W1 & .84 & 35.14 & .000 \\
& W2 & .79 & 26.13 & .000 \\
& W3 & .82 & 28.90 & .000 \\
& W4 & .81 & 27.99 & .000 \\
& W5 & .81 & 28.06 & .000 \\
& W6 & .84 & 29.64 & .000 \\
& W7 & .79 & 20.23 & .000 \\
& W8 & .79 & 21.47 & .000 \\
\hline
\end{tabular}

\section{Discriminant Validity}

Discriminant validity can be defined as any single construct when differs from other constructs in the model (Carmines \& Zeller, 1979). Discriminant validity results are satisfactory when the constructs have an AVE loading more than.5 which means that minimum $50 \%$ of variance was took by the construct (Chin , 1998). Discriminant validity is established if the elements which are in diagonal are significantly higher than those values in off-diagonal in the parallel rows and columns. Discriminant Validity tests are being conducted in order to see whether non-related ideas or measurements are in fact unrelated or not. An effective assessment of discriminant legitimacy demonstrates that a trial of an idea is not exceptionally associated with different tests intended to quantify hypothetically various ideas. The validity is determined when the values in diagonal is higher than those which are in parallel row and column. All the values in the table is more than 0.5 except the value of employee trust and occupational selfefficacy which indicates that these elements do not have significant relationship in real. Furthermore, results show that discriminate validity results are satisfactory. Table 8 presents the results for discriminant validity.

Table 8

Discriminant Validity Results

\begin{tabular}{|c|c|c|c|c|}
\hline Variables & $\begin{array}{l}\text { Authentic } \\
\text { Leadership }\end{array}$ & Employee Trust & $\begin{array}{l}\text { Occupational } \\
\text { efficacy }\end{array}$ & $\begin{array}{l}\text { Self- Work } \\
\text { Engagement }\end{array}$ \\
\hline Authentic Leadership & .71 & & & \\
\hline Employee Trust & .70 & .78 & & \\
\hline Occupational Self-efficacy & .57 & .44 & .86 & \\
\hline Work Engagement & .76 & 68 & .59 & .81 \\
\hline
\end{tabular}

\section{Model Fit Measures}

The fitness of the model in SEM-PLS is defined by various measures such as standardized rootmean-square residual (SRMR), and the exact model fits like d_ULS and d_G, Normed Fit Index (NFI), and $\chi^{2}$ (Chi-square). The model fit measures consisting of the measured value of both 
saturated model as well as the estimated model are reported in Table 9. The saturated model assesses the correlation between all constructs. The estimated model, on the other hand, takes model structure into account and is based on total effect scheme.

Table 9

Model Fit Measures

\begin{tabular}{lll}
\hline Fit Summary & Saturated Model & Estimated Model \\
\hline SRMR & .10 & .10 \\
d_ULS & 3.34 & 3.32 \\
d_G & 1.29 & 1.29 \\
Chi-Square & 1287.01 & 1285.17 \\
NFI & .65 & .66 \\
\hline
\end{tabular}

\section{Hypothesis Testing}

\section{PLS Algorithm}

As illustrated in Figure 2, the Path model built in accordance with the research questions indicates that all the paths of this model are significant. The path coefficient of authentic leadership to employee trust, occupational self-efficacy and employee work engagement is $0.703,0.578$ and 0.429 indicates a meaningful relationship and explains that variation caused in the dependent variable $(70.3 \%$ in employee trust, $57.8 \%$ in Occupational self-efficacy and $42.9 \%$ in employee work engagement) is significant owing to the t-values which are greater than 1.96. The $\mathrm{p}$ values are 0.000 which is less than 0.05 and based on $\mathrm{P}$ value the alternative hypothesis has been supported.

The path coefficient of authentic leadership to employee trust, occupational self-efficacy and employee work engagement is .703, .578 and .429 which indicates a meaningful relationship and explains that variation caused in the dependent variable $(70.3 \%$ in employee trust, $57.8 \%$ in Occupational self-efficacy and $42.9 \%$ in employee work engagement) is significant owing to the t-values which are greater than 1.96 . The $p$ values are .000 which is less than .05 and on the basis of $p$ value, the alternative hypothesis has been supported. It is accepted that the authentic leadership has a positive influence on employee trust, occupational self-efficacy and employee work engagement.

The path coefficient of employee trust to work engagement is .290 which depicts a meaningful relationship and explains that variation caused in the dependent variable, i.e., $29.0 \%$ in employee work engagement is significant owing to the t-values which are greater than 1.96. The $p$ values are .000 which is less than .05 and on the basis of $p$ value, the alternative hypothesis has been supported. It is accepted that employee trust has a positive influence on work engagement.

The path coefficient of employee occupational self-efficacy to work engagement is .220 which indicates a meaningful relationship and explains that variation caused in the dependent variable (i.e., $22.0 \%$ in employee work engagement) is significant owing to the t-values which are greater than 1.96. The $p$ values are .002 which is less than .05 and on the basis of $p$ value, the alternative hypothesis has been supported. It is accepted that employee occupational selfefficacy has a positive influence on employee work engagement. 


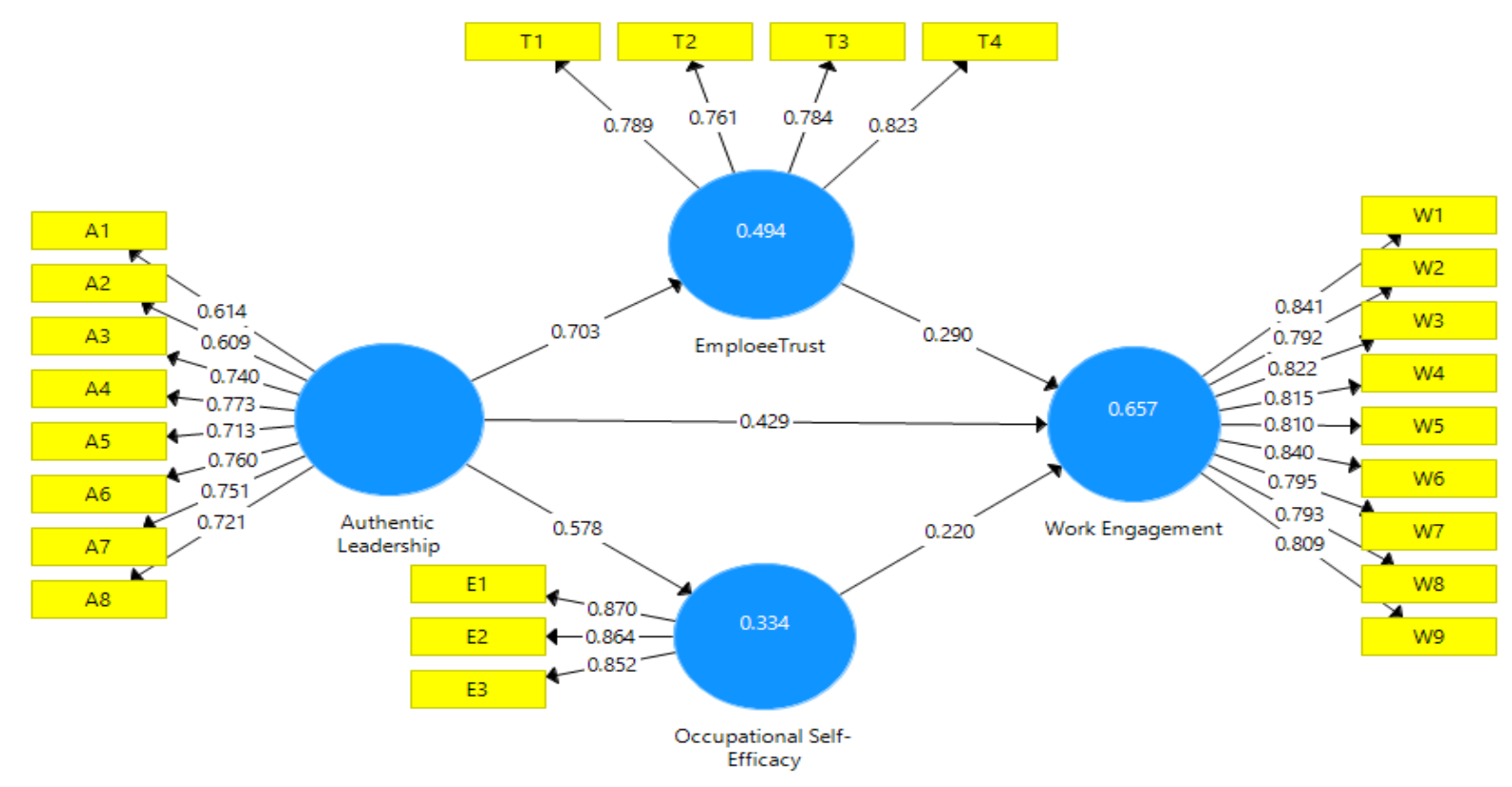

Figure 2. Path coefficient

\section{PLS Bootstrapping}

In PLS-SEM, bootstrapping is one of the key strides which gives the data of constancy of factor guesstimate. Sub-tests are drawn everywhere from the first example including substitution (Hair, Matthews, Matthews, \& Sarstedt, 2017). Bootstrapping provides the information of stability of the coefficient estimate. In this process, many sub-samples are drawn from the original sample with replacement ( Hair, Sarstedt, Matthews, \& Ringle, 2016). Figure 3 represent the PLS-SEM bootstraping.

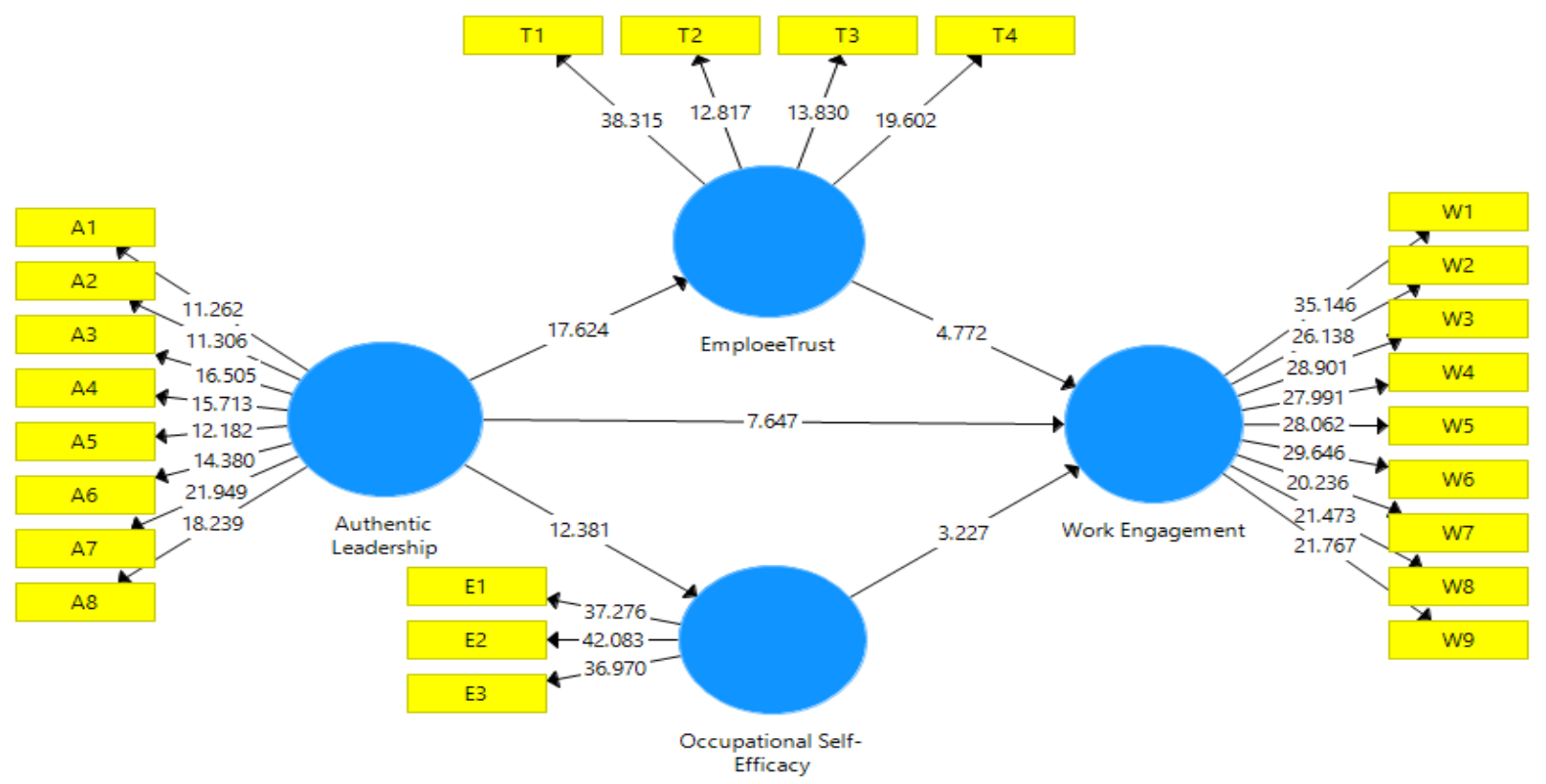

Figure 3. PLS-SEM bootstraping

After running the bootstrap routine, SmartPLS shows the t-values for structural model estimates derived from the bootstrapping procedure. The results of path coefficients for all the hypothesis are shown in Table 10. The t-value greater than $1.96(p<.005)$ shows that the 
relationship is significant at 95\% confidence level $(\alpha=.05)$. Paths show whether the relationship between measured and latent variables are significant or not. To study the relationship among these variables bootstrapping method in Smart PLS was used and the results will determine whether to accept/ reject the proposed hypothesis.

Table 10

Path Coefficients for all the Hypotheses

\begin{tabular}{|c|c|c|c|c|}
\hline Hypotheses & Path Coefficient & $t$ & $p$ & Conclusion \\
\hline $\mathbf{H}_{1}$-AuthenticLeadership- Employee Trust & .70 & 17.62 & .000 & Supported \\
\hline $\mathbf{H}_{2}$ Employee Trust - Work Engagement & .29 & 4.77 & .000 & Supported \\
\hline $\mathbf{H}_{3}$-Authentic Leadership - Occupational Self-efficacy & .57 & 12.38 & .000 & Supported \\
\hline $\mathbf{H}_{4}$-Occupational Self-efficacy -Work Engagement & .22 & 3.22 & .001 & Supported \\
\hline $\mathbf{H}_{5}$-Authentic Leadership -Work Engagement & .42 & 7.64 & .000 & Supported \\
\hline
\end{tabular}

\section{Mediating role of Employee Trust and Occupational Self-efficacy}

The mediating role of employee trust and occupational self-efficacy in the relationship of authentic leadership and work engagement is assessed by the indirect effects of the bootstrapping test. As shown in Table 11, the $t$ values indicate a significant relationship among the variables as the $t$ values are 4.58 and 3.09 greater than 1.96 . The $p$ values are .000 which is less than .05 and on the basis of $p$ value, the alternative hypothesis has been supported. Thus, it is proved that employee trust and occupational self-efficacy have the mediating effect on the relationship between authentic leadership and work engagement.

Table 11

T-Values of the Bootstrapping Test

\begin{tabular}{lccc}
\hline Hypothesis & $t$ & $p$ & Conclusion \\
\hline $\mathbf{H}_{\mathbf{6}}$-AuthenticLeadership Employee Trust - Work Engagement & 4.58 & .000 & Supported \\
$\mathbf{H}_{\mathbf{6} \mathbf{b}}$-Authentic Leadership - Occupational Self-efficacy & 3.09 & .002 & Supported \\
\hline
\end{tabular}

\section{Discussion}

The findings of this study support the previous studies (Hassan \& Ahmed , 2011) and indicate that the authentic behavior of leaders promotes healthy work environment that fosters trust level of employees. When leaders are authentic, genuine and honest towards their employees and maintain transparency in an organization, it influences employee trust level that results in an increased work engagement. Furthermore, the results are supported by Hsieh and Wang's (2015) research sated that the relational transparency behavior exhibited by authentic leader influences employee trust level. When a leader openly shares ideas, opinions and clearly states what is expected from them employees will trust their leader more and will be more willing to get themselves engaged. Moreover, employees always trust their leaders when they are consistent with their words and actions, and this consistent behavior has a positive impact on employee work engagement. This study also highlights that employee trust acts as a mediator between authentic leadership and employee work engagement and the relationship is strengthened when the trust level is maintained.

Past studies focused only on one variable, i.e., employee trust that has a positive relationship with authentic leadership and affects employee's work engagement (Hassan \& Ahmed , 2011; Hsieh \& Wang, 2015). We strived to fill the research gap by examining the other factors that influence work engagement and examined the role of occupational self-efficacy in promoting the work engagement of employees and its relationship with authentic leadership. This study found a positive relationship among these variables and reports that when a leader exhibits a behavior of self-awareness, it has a positive impact on employees. When a leader is self-aware 
of their strengths, weaknesses, moral values and beliefs, they become a role for their employees and inspires them. This inspiration leads to a positive attitude and a high level of self-efficacy. Authentic leaders encourage their employees to maximize their strengths and overcome their weaknesses which promotes their self-confidence and self-esteem and results in an increased level of occupational self-efficacy. The leader's confidence in their employees that they will perform in an efficient manner boosts the self-efficacy level of employees. The findings of our research are supported by previous studies done by Avolio and Luthans (2006). This study also reveals the mediating effect of occupational self-efficacy between authentic leadership and employee engagement. Furthermore, the present study found a positive mediating influence of occupational self-efficacy on the relationship between authentic leadership and employee work engagement and the results are supported by the research conducted by Fallatah and Laschinger (2017) and Kim (2014).

Finally, the study hypothesized the direct influence of authentic leadership and employee work engagement and found a significant relationship among these variables. The results are supported by previous studies (Gardner, Avolio, Luthans, May, \& Walumbwa, 2005; Walumbwa, Wang, Wang, Schaubroeck, \& Avolio, 2010) sated that the genuine, honest and authentic behavior of leaders inspires their employees. Authentic leaders clearly communicate what is expected, share the relevant information and ideas, maintain the transparency in an organization by making fair decisions based on key values, remain self-aware of their strengths and weakness and promote a healthy work environment by encouraging their employees that results in increased work engagement.

This study is based on the perspective of social exchange theory (Blau, 1964) and argues that the positive effect of authentic leadership is based on the perception of employees and when employees perceive their leader's behavior as authentic, genuine and honest they will tend to repay them for the benefits they receive by engaging in their work. The results are supported by the research conducted by Abidin and Noraida (2017) and Hsieh and Wang (2015). Thus, a win win situation is created when a leader acts genuinely and honestly which reflects who they are (Rouse, 2018). They are self-aware of their strong and weak points, prioritize targets and mission of the organization (Kruse, 2013) and perform in a manner consistent to their values and beliefs (Avolio, Gardner, Walumbwa, Luthans, \& May, 2004) and the employees perceive that supervisors value their feelings results in an increased work engagement (Hsieh \& Wang, 2015).

\section{Conclusion}

This study investigated the effect of authentic leadership on employees' trust, occupational self-efficacy and work engagement. It also explored the mediating role of employee trust and occupational self-efficacy between these variables. In this study, we have used the instruments that were already developed and validated by researchers and supported by many studies mentioned in literature review. To confirm the reliability and consistency of measuring instruments Cronbach's alpha was used. The correlation among the variables were measured by spearman rank correlation and the consistency of scale items were measured by composite reliability. Bootstrapping test was used to study the relationship, and the association among the variables were determined by the path coefficient of path model. The results indicated the positive association among these variables and found a positive mediating effect of employee 
trust and occupational self-efficacy between authentic leadership and employee work engagement. This research hypothesized that authentic leadership positively influence employee trust and the results of the present study revealed that there is a significant relationship between these variables.

The study was conducted to better understand the value of authentic leadership and its impact on employee's attitude, work engagement and the mediating role of employee trust and occupational self-efficacy. It found a strong and positive relationship among the variables. The impact of authentic leadership in developing employee trust level and occupational selfefficacy was significant. There was a direct and positive relationship between authentic leadership and work engagement. The employee trust and self-efficacy act as a mediating tool to mediate and strengthen the relationship between authentic leadership and work engagement.

This study highlights the vital role that authentic leaders play in motivating employees to bring positive change in employees' attitude, the trusting relationship that is maintained when a leader is genuine and honest and the efforts made to build confidence of the employees to achieve a high level of self-efficacy.

Therefore, it is important for a leader to develop positive traits and remain positive, selfaware and confident. To survive in a dynamic and competitive world, positive attitude and behavior are key driving forces that motivate, encourage and inspire the employees to accomplish their tasks effectively.

\section{Limitations and Suggestions}

One of the main limitations of this study was the shortage of time and budget constraint due to which quantitative method was adopted to gather the data. The sample size comprised of 200 employees and does not represent the entire population of Pakistan. To analyze the data, we have used convenience sampling technique which does not cover every sector of Pakistan. Moreover, employees were reluctant to provide the accurate data. This study is based on the perspective of the employees only, and does not explore authentic leadership from supervisors' perspective. Further research is required to explore this relationship from the perspective of both supervisor and employee. Sample size should be increased to cover the other regions of Pakistan in order to represent the population. Cultural variables may also be included for the future research purpose to examine the relationship between authentic leadership and work engagement because the culture of an organization determines the leadership style of a leader.

\section{References}

Abidin, S. Z., \& Noraida, S. (2017). The effect of perceived authentic leadership on employee engagement. Journal of Tourism, Hospitality and Environment Management, 2(4), 29-47.

Avey, J. B., J, R., Reichard, Luthans, F., \& Mhatre, K. H. (2011). Meta-analysis of the impact of positive psychological capital on employee attitudes, behaviors, and performance. Human Resource Develpment Quarterly, 22(2), 127-152.

Avolio, B. J., \& Gardner, W. L. (2005). Authentic leadership development: Getting to the root of positive forms of leadership. The Leadership Quarterly, 16, 315-338.

Avolio, B. J., Gardner, W. L., Walumbwa, F. O., Luthans, F., \& May, D. R. (2004). Unlocking the mask: A look at the process by which authentic leaders impact follower attitudes and behaviors. The Leadership Quarterly, 15, 801-823.

Avolio, B. J., \& Luthans, F. (2006). The high impact leader: Moments matter for accelerating authentic leadership development. New York: McGraw-Hill Education. 
Babcock-Roberson, M., \& Strickland , O. (2010). The relationship between charismatic leadership, work engagement, and organizational citizenship behaviors. The Journal of Psychology: Interdisciplinary and Applied, 144(3), 313-326.

Bakker, A. B. (2011). An evidence-based model of work engagement. Current Directions in Psychological Science, 20(4), 265-269.

Bandura, A. (1982). Self-efficacy mechanism in human agency. American psychologist, 37(2), 122-147.

Bandura, A. (1997). Self-efficacy: The exercise of control. New York: WH Freeman and Company.

Bandura, A. (1999). Social cognitive theory: An agentic perspective. Asian Journal of Social Psychology, 2, 21-41.

Baron, R., \& Kenny, D. (1986). The moderator-mediator variable distinction in social psychological research: conceptual, strategic, and statistical considerations. Journal of Pe nality and Social Psychology, 51(6), 1173-1182.

Bennis, W. G. (1989). Managing the dream: Leadership in the 21st century. Journal of Organizational Change Management, 2(1), 6-10.

Bennis, W., \& Nanus, B. (1985). Leaders: The strategies for taking charge. New York: Harper and Row.

Block, P. (1993). Stewardship: Choosing service over self-interest. San Francisco: Berrett Koehler.

Bohn, J., D., P., \& Grafton. (2002). The relationship of perceived leadership behaviors to organizational efficacy. Journal of Leadership and Organizational Studies, 9(2), 65-79.

Brad, S., \& Karen, W. (2010). Employee engagement and HRD: A seminal review of the foundations. Human Resource Development Review, 9(1), 89-110.

Blau, P. M. (1964). Exchange and power in social life. Newyork: John Wiley \& Sons.

Breevaart, K., Bakker, A., Hetland, J., Demerouti, E., Olsen, O. k., \& Espevik, R. (2013). Daily transactional and transformational leadership and daily employee. Journal of Occupational and Organizational Psychology, 87, $138-157$.

Carmines, E., \& Zeller, R. (1979). Reliability and validity assessment. United States: Thousand Oaks.

Cassidy, S., \& Eachus, P. (2002). Developing the computer user self-efficacy (cuse) scale: investigating the relationship between computer self-efficacy, gender and experience with computers. Journal of Educational Computing Research, 133153.

Chhetri, P. (2014). The role of cognitive and affective trust in the relationship between organizational justice and organizational citizenship behavior: a conceptual framework. Verslas: Teorija Ir Praktika, 15(2), 170-178.

Chin , W. W. (1998). The partial least squares approach for structural equation modeling. In G. A. Marcoulides (Ed.), Methodology for business and management. Modern methods for business research (p. 295-336). Lawrence Erlbaum: Associates Publishers.

Dar, F., Bukhari, I., \& Hamid, M. (2016). Relationship between authentic leadership, work engagement and job stress among employees of telecommunication organizations. Peshawar Journal of Psychology and Behavioral Sciences, 2(2), 235-248.

Darvish, H., \& Rezaei, F. (2011). The impact of authentic leadership on job satisfaction and team commitment. Management and Marketing, 6(3), 421-436.

Dirks, K. T., \& Ferrin, D. L. (2002). Trust in leadership: Meta-analytic findings and implications for research and practice. Journal of Applied Psychology, 87(4), 611-628.

Eden, D. (2003). Self-fulfilling prophecies in organizations. In J. Greenberg (Ed.), Organizational behavior: The state of the science (p. 91-122). Lawrence Erlbaum: Associates Publishers.

Fallatah, F., \& Laschinger, H. K. (2017). The effects of authentic leadership, organizational identification, and occupational coping self-efficacy on new graduate nurses' job turnover intentions in Canada. Nursing Outlook, 65(2), 172-183.

Fornell, C., \& Larcker, D. F. (1981). Structural equation models with unobservable variables and measurement error: Algebra and statistics. Journal of Marketing Research, 18(3), 382-388.

Gardner, W. L., Avolio, B. J., Luthans, F., May, D. R., \& Walumbwa, F. (2005). Can you see the real me? A self-based model of authentic leader and follower development. The Leadership Quarterly, 16, 343-372.

Gardner, W., \& Schermerhorn, J. R. (2004). Unleashing individual potential: Performance gains through positive organizational behavior and authentic leadership. Organizational Dynamics, 270-281.

George, B. (2003). Authentic leadership rediscovering the secrets to creating lasting value. San Francisco: Jossey-Bass.

George, B., Sims, P., McLean, A. N., \& Mayer, D. (2007). Discovering your authentic leadership. Harvard Business Review, $85(2), 129$.

Gerstner, C. R., \& Day, D. V. (1997). Meta-Analytic review of leader-member exchange theory: Correlates and construct issues. Journal Of Applied Psychology, 82(6), 827-844. 
Giallonardo, L. M., Wong, C. A., \& Iwasiw, C. L. (2010). Authentic leadership of preceptors: predictor of new graduate nurses' work engagement and job satisfaction. Journal of Nursing Management, 18(8), 993-1003.

Glen, C. (2006). Key skills retention and motivation: the war for talent still rages and retention is the high ground. Industrial and Commercial Training, 38(1), 37-45.

Guarnaccia, C., Scrima, F., Civiller, A., \& Salerno, L. (2016). The role of occupational self-efficacy in mediating the effect of job insecurity on work engagement satisfaction and general health. Current Psychology, 37(3), 488-497.

Hair, J. F., Jr, Sarstedt, M., Matthews, L. M., \& Ringle, C. M. (2016). Identifying and treating unobserved heterogeneity with FIMIX-PLS: part I - method. European Business Review, 28(2), 63-76.

Hair, J. F., Matthews, L. M., Matthews, R. M., \& Sarstedt, M. (2017). PLS-SEM or CB-SEM: updated guidelines on which method to use. International Journal of Multivariate Data Analysis, 107-123.

Harter, S. (2002). Authenticity. In C. R. Snyder, \& S. J. Lopez (Eds.), Handbook of positive psychology (pp. 382-394). London: Oxford University Press.

Hassan, A., \& Ahmed, F. (2011). Authentic leadership, trust, and employees' work engagement. International Journal of Human and Social Sciences, 6(3), 164-170.

Hayes, A. F. (2013). Introduction to mediation, moderation, and conditional process analysis. Journal of Educational Measurement, 51(3), 335-337.

Hopper, E. (2019). Thoughtco. Retreived from https://www.thoughtco.com/self-efficacy-4177970

Hsieh, C. C., \& Wang, D. S. (2015). Does supervisor-perceived authentic leadership influence employee work engagement through employee-perceived authentic leadership and employee trust? The International Journal of Human Resource Management, 26(18), 2329-2348.

Ilies, R., Morgeson, F. P., \& Nahrgang, J. D. (2005). Authentic leadership and eudaemonic well-being understanding leaderfollower outcomes. The Leadership Quarterly, 16, 373-394.

Jiang, H., \& Luo, Y. (2018). Crafting employee trust: From authenticity, transparency to engagement. Journal of Communication Management, 22(2), 138-160.

Kahn, W. A. (1990). Psychological conditions of personal engagement and disengagement at work. Academy of management journal, 33(4), 692-724.

Kernis, M. H. (2003). Target article: toward a conceptualization of optimal self-esteem. psychological inquiry. An International Journal for the Advancement of Psychological Theory, 14(1), 1-26.

Khan, S., Muhammad, B., Afridi, G. W., \& Sarwar, I. (2017). Effect of authentic leadership on job satisfaction and employee engagement. City University Research Journal, 7, 151-166.

Kim, H. K. (2014). The effect of authentic leadership on employees' attitudes, behaviors, and performances in a Korean context (Unpublished doctoral dissertation). Oklahoma State University.

Korthuis-Smith, W. (2000). Organizational trust: The leadership challenge. Paper presented at the symposium conducted at the Leadership for a Global Community conference, Seattle.

Kruse, K. (2013). Forbes. Retreived from https://www.forbes.com/sites/kevinkruse/2013/05/12/what-is-authenticleadership/\#249a61e8def7

Kurbanoglu, S., Akkoyunlu, B., \& Umay, A. (2006). Developing the information literacy self-efficacy scale. Journal of Documentation, 62(6), 730-743

Lewis, J. D., \& Weigert, A. (1985). Trust as a Social Reality. Social Forces, 63(4), 967-985.

Luthans, F., Avey, J. B., \& Patera, J. L. (2008). Experimental analysis of a web-based training intervention to develop positive psychological capita. Academy of Management Learning \& Education, 7(2), 209 -221.

Luthans, F., \& Avolio, B. J. (2003). Authentic leadership development. In K. S. Cameron, J. E. Dutton, \& R. E. Quinn (Eds.), Positive organizational scholarship (pp. 241-258). San Francisco, CA: Berrett-Koehler.

McAllister , D. J. (1995). Affect- and cognition-based trust as foundations for interpersonal cooperation in organizations. Academy of Management Journal, 38(1), 24-59.

Mayer, R. C., Davis, J. H., \& Schoorman, F. D. (1995). An integrative model of organizational trust. The Academy of Management Review, 20(3), 709-734

Mills, M. J., Fleck, C. R., \& Kozikowski, A. (2013). Positive psychology at work: A conceptual review, state-of-practice assessment, and a look ahead. The Journal of Positive Psychology, 8(2), 153-164

Neider, L. L., \& Schriesheim, C. A. (2011). The authentic leadership inventory (ALI): Development and empirical tests. The Leadership Quarterly, 22(6), 1146-1164. 
Norman, S. M. (2006). The role of trust: Implications for psychological capital and authentic leadership. ETD collection for University of Nebraska - Lincoln. AAI3208085.

Retreived from https://digitalcommons.unl.edu/dissertations/AAI3208085

Oh, J., Cho, D., \& Lim, D. H. (2018). Authentic leadership and work engagement: the mediating effect of practicing core values. Leadership \& Organization Development Journal, 39(2), 276-290.

Oreg., S. (2003). Resistance to change: Developing an individual differences measure. Journal of Applied Psychology, 88(4), 680-693.

Rego, A., Sousa, F., Marques, C., \& Cunha, M. P. (2012). Authentic leadership promoting employees' psychological capital and creativity. Journal of Business Research, 65(3), 429-437.

Rigotti, T., Schyns, B., \& Mohr, G. (2008). A short version of the occupational self-efficacy scale: structural and construct validity across five countries. Journal of Career Assessment, 16(2), 238-255.

Robinson, S., \& O’Dea, V. (2014). Authentic leadership: To thine own self be true. United Kingdom: Insights. Retrieved 2014 from www.insights.com.

Rouse, M. (2018). SearchCIO. Retreived from https://searchcio.techtarget.com/definition/authentic-leadership

Roux, S. (2010). The relationship between authentic leadership, optimism self-efficacy and work engagement: an exploratory study (Unpublished doctoral dissertation), University of Stellenbosch: Stellenbosch.

Saks, A. M. (2006). Antecedents and consequences of employee engagement. Journal of Managerial Psychology, 21(7), 600619.

Schaufeli, W. B., \& Bakker, A. (2003). Utrecht work engagement scale-preliminary manual. Utrecht: Utrecht University, Occupational Health Psychology Unit.

Schaufeli, W. B., \& Bakker, A. B. (2006). The measurement of work engagement with a short questionnaire. Educational and Psychological Measurement, 66(4), 701-716.

Schaufeli, W. B., Salanova, M., González-romá, V., \& Bakker, A. B. (2002). The measurement of engagement and burnout a two sample confirmatory factor analytic approach. Journal of Happiness Studies, 3(1), 71-92.

Shaw, R. B. (1997). Trust in the balance: Building successful organizations on results, integrity and concern. San Francisco: Jossey-Bass.

Shrout, P. E., \& Bolger, N. (2002). Mediation in experimental and nonexperimental studies: new procedures and recommendations. Psychological Method, 7(4), 422-445.

Schyns, B., \& Collani, G. V. (2002). A new occupational self-efficacy scale and its relation to personality constructs and organizational variables. European Journal of Work and Organizational Psychology, 11(2), 219-241.

Sonnentag, S. (2003). Recovery, work engagement, and proactive behavior: A New Look at the interface between nonwork and work. Journal of Applied Psychology, 88(3), 518-528.

Sweetman, D., \& Luthans, F. (2010). The power of positive psychology: Psychological capital and work engagement. In A. B. Bakker \& M. P. Leiter (Eds.), Work engagement: A handbook of essential theory and research (p. 54-68). United Kingdom: Psychology Press.

Tims, M., Bakker, A. B., \& Xanthopoulou, D. (2011). Do transformational leaders enhance their followers' daily. The Leadership Quarterly, 22(1), 121-131.

Ugwu, F. O., Onyishi, I. E., \& Rodri'guez-Sa'nchez, A. M. (2014). Linking organizational trust with employee engagement: the role of psychological empowerment. Personnel Review, 43(3), 377-400.

Walumbwa, F. O., Avolio, B. J., Gardner, W. L., Wernsing, T. S., \& Peterson, S. J. (2008). Authentic leadership: Development and validation of a theory-based measure. Journal of Management, 34(1), 89-126.

Walumbwa, F. O., Wang, P., Wang, H., Schaubroeck, J., \& Avolio, B. J. (2010). Psychological processes linking authentic leadership to follower behaviors. The Leadership Quarterly, 21(5), 901-914.

Wang, D. S., \& Hsieh, C. C. (2013). The effect of authentic leadership on employee trust and employee engagement. Social Behavior and Personality: An International Journal, 41(4), 613-624.

Wee, T. C. (2013). Talent retention: The pressures in Malaysia SMEs. American Journal of Economics, 3(5), 35-40.

Wong, C. A., \& Cumming, G. G. (2009). The influence on authentic leadership behaviors on trust and work outcomes of healthcare staff. Journal of Leadership Studies, 3(2), 6-23. 